\title{
Factors Influencing MICE Tourism Development In Pulau Seribu, Jakarta, Indonesia
}

\author{
Jihad Ghaffara $^{1,}$ Gareth Currie $^{2,}$ Nurima Rahmitasari ${ }^{3}$ \\ ${ }^{1}$ Sekolah Tinggi Pariwisata Trisakti \\ ${ }^{2}$ International Management Institute, Switzerland \\ ${ }^{3}$ Sekolah Tinggi Pariwisata Trisakti \\ 3nurima@stptrisakti.ac.id
}

\begin{abstract}
This research aims to investigate the factors influencing MICE development in Pulau Seribu. Primary research data are collected by using questionnaire to analyse the market condition, demand, and potential factors in MICE industry. The results discover that the main factors influencing MICE tourism development in Pulau Seribu are infrastructure and marketing. In addition, the research has found that service provider industry is the main target market as meeting and incentives trip for the potential target market as an MICE tourism activity. Also, this research shows the correlation with the theory of infrastructure as one of the most factors that can influence MICE tourism by Swarbrooke \& Horner (2001), and Nawrocka theory (2013).
\end{abstract}

Keywords: MICE tourism products, tourism development, Pulau Serbia 


\section{A. Introduction}

The research aims to investigate the growth in the business events industry in Pulau Seribu, Indonesia. The authors conduct primary research to investigate the current situation in regard to MICE tourism on Pulau Seribu and finally provide recommendations to stakeholders on the island with a view to encouraging further growth of MICE industry sector. In general, the tourism industry is a service industry that provides basic tourist needs like accommodation, transportation, and also foods \& beverages. This industry is currently growing over the world. According to the survey result of Statista Inc., tourism industry has developed quickly and now tourism industry already become top industries in the world (Statista, 2016).

Globalization also gives a significant impact to the growth and changes in tourism industry. Open market economic and free human movement cause a rapid tourism development in the world (UNWTO, 2010, cited in Klimek, 2013:4). Mass Tourism and Sustainable Tourism are two examples of characteristics that occur because of the globalization effect. Those characteristic have an opposite meaning. As stated by UNWTO (1996, cited in Klimek, 2013), sustainability tourism is a tourism industry that maintaining tourist needs with the culture and ecological value. And the definition of mass industry is, where the industry only produces and promotes their product focusing on tourist needs (Weaver and Lawton, 2002:471, cited in Weaver, 2013).

The development in tourism industry can be seen from all of different type of customer needs such as business, health, religion, culture, leisure, and also family needs. Meeting, incentives, convention, and exhibition are the example of a product evolution within the tourism industry.

MICE is an acronym of meeting, incentive, convention, and exhibition business in tourism industry. MICE industry is an industry that provides all the elements of services that needed to create an event (Brotherton\& Wood, 2008:400). The industry now provides not only for people seek leisure, but also for work and business purpose. MICE industry is an important supporting factor for the progress of the tourism industry and the economic sector of a country (Smagina, 2017). For the developing country in the Asia pacific, they now compete with each other to become the next destination of MICE tourism industry.

MICE tourism industry in ASEAN has a really advance growth, and unconsciously has become one of the major industrial markets in ASEAN. Several cities in Southeast Asia are cooperating among countries to prepare themselves for the development of mice tourism industry. Also according to ASEAN (2016), tourist that comes with the purpose of MICE has more buying power.

The Republic of Indonesia is a country located in Southeast Asia with the largest archipelago in the world. Through the improvement in their tourism 
industry, Indonesia is currently planning to promote their tourism industry to the world. The Indonesian government also has other plans to develop tourism industry, such as improving MICE tourism industry in Indonesia. Based on the survey of the International Congress and Convention Association statistic report or ICCA (2016), Indonesia is included in the eleven ranks of the city with its annual number of meetings for the south eastern Asia and middle-eastern region. In this country, the government plan for the development of MICE industry and focusing on 10 cities in Indonesia. From all of the 10 cities that are mentioned in the plan, Jakarta is one of the cities that have the potential and also adequate facilities to develop the MICE tourism industry faster than other cities. Jakarta has experience in hosting an internationalMICE event.

According to Head of Jakarta Development Planning Agency (BAPPEDA) (2015, cited in Tempo.co, 2015), Jakarta will make MICE tourism industry as the concept of development of tourism industry and this concept will be divided into two parts: the cities and island. When the city area in Jakarta is ready with infrastructure and facilities for the MICE tourism industry development, conditions in the archipelago Jakarta or more precisely, in Pulau Seribu is still inadequate due to lack of development.

\section{Problem Identification}

As MICE industry in Indonesia is increasingly growing, Jakarta has the most potential in the development of this industry with its experience in hosting an international event and it readily available of infrastructure. Moreover, one of the most likely to be developed area is Pulau Seribu due to its potential and strategic location. However, some factors affecting the developing process of this tourism industry exist. (Buhalis, 2006).

\section{Problem Limitation}

This research focuses on the factors influencing the developmentof MICE tourism in Pulau Seribu, Indonesia.

\section{Objectives}

The aims of this research are as the following:

A. To critically review secondary literature on tourism development with a focus on business tourism to provide a framework for the research.

B. To investigate the potential of Pulau Seribu to increase the MICE carrying capacity of the local region; and

C. To provide recommendations to the tourism stakeholders of Pulau Seribu on strategies that could be used to increase business tourism to the location. 


\section{B. Literature Review}

According to Lickorish and Jenkins (1997), tourism industry went through four stages of development: prehistory tourism, transport, interwar period, and tourism take-off. Now in the present world tourism has developed to be a popular activity, this is proven by the mass tourism phenomena. Mass tourism is a cultural phenomenon, when a massive group of people travel to the same destination at the same time (Pons, 2016;Sezgin and Yolal, 2012).

There are many aspects that influence tourism to develop, and cause the evolution of tourism to become a business industry. According to Patil (2013), environmental, socio-economic, historical and cultural, religious, are the five factors that affect the growth of the tourism industry. The development of tourism has led to the creation of four classifications of tourism based on typology: organized mass tourism, individual mass tourism, explorers, and drifters (Cohen, 1972, cited in Mason, 2008).

Customers are one of the important elements influencing the development of the tourism industry. The development of the tourism industry happened because they need to meet customers demand (Hayward, 2000). Marshall ${ }^{\text {ee }}$ theory of demand identifies that demands is affected by price and quantity, in this theory demand is define as a willingness of a person to spend their money for something according to quantity of the goods itself (Marshall, 1920, cited in Aldrich, 1996). The changes of demand in modern life are not only affected by economic value, but also social value like culture, fashion, and entertainment (Holloway and Humphreys, 2012; Arnold, 2007).

A research theory called Tourist Area Life Cycle (TALC) facilitates understanding the progress of tourism development in certain area.In the seven stages of tourism development in Tourist Area Life Cycle (TALC) research theory model, each stage has a different characteristic of development: exploration (tourist started to interact with the locals), involvement (the beginning of tourism business creation), development (the stage when international tourism enter the destination), consolidation (slowing rate of tourist visitor growth, and when the market condition starts to be controlled by foreign companies), stagnation (The growth of tourism comes to an end, and the market is focusing on returning customer or repeat tourism), decline (a declining market stage when there is no more innovation and the destination is not able to compete with others), rejuvenation (in this stage is when the destinations try to create innovative effort by offer something new to the market) (Butler, 2006).

The main goal of tourism is to satisfy the tourist (Bastola, 2012). According to CSSP (2007:6), by monitoring the satisfaction level of customers can help companies to maintain stability and quality. William et al (in Sharma Savita and Sidharth Srivastava, 2018) said that customers are considered to be satisfied when their expected service performance matches with the delivered service performance. One of the ways to satisfy customers is to identify their 
motivation. Motivation basically is a human need that is divided into physical and emotional needs (Holloway and Humphreys, 2012). According to Maslow (2012), human needs divide into five categories: self-actualization, esteem, love or belonging, safety, and physiological (Figure 2.2). There is a process to understand the needs of customers, and this process is called motivation process (Holloway and Humphreys, 2012).

\section{Modern Tourism}

In the modern time, tourism has already become an international commerce business equals with the other top industries (UNWTO, 2017). The fast growth of tourism has led the industry to evolve into a new form. The modern tourism business industry has five main sectors of industry

accommodation, attractions, transport, travel organizers ${ }^{e e}$ and destination organization (Middleton and Clarke, 2001).

This modern tourism industry has also created new trends of tourism; this new trend is business tourism when people travel with a purpose for a business. Airlines, hotel, and food and beverages are a top category of business travel expense (Tribe, 2011). Travel with the combined purpose of leisure and business is a new trend in tourism industry called "bleisure" (Burkhard, 2016; Lichy and McLeay, 2017).

\section{Business Tourism}

Business tourism is a business with a variety of forms. Commercial, government, and educational, and also with different segmentation characteristics like individual, group, event (MICE), and training (Nicula and Elena, 2014). Meeting, negotiating, and presentation is the basic general activity of business traveller (Hotelrez, 2015).According to UNWTO survey (2017), the tourism business market has a considerable market share in the world's tourism industry with $13 \%$ of tourism visits for the purpose of business and professional travel. According to Avramović (2016), There are four fundamental purpose keys in modern business tourism is meetings and conferences, incentive travel, exhibitions or fairs, and individual business travel (delegation).

\section{MICE Tourism}

MICE is a modern term to categories meetings, incentives, conferences and exhibition Industry for business tourism (Ladkin and Spiller, 2000). According to Sylla (2015), MICE is when there is one events planned that connects groups of people in business tourism activities. In this industry the group customers are more important, because its easier to take care and more certain as a market (Avramović, 2016). Also according Avramović (2016), group customers in the MICE industry are categorized into four groups: conventions; association meetings; corporate meetings; and SMERF (social, military, educational, religious, and fraternal organization) groups. 
There are several factors that influence the growth of MICE tourism in one destination. There are several traits that can influence the MICE tourism industry like demand of the market; venue criteria selection; technology; and marketing (Buhalis, 2006). Location and accommodation, transportation and accessibility, and the image of the destination are the main factors that influence the choice of destination for business travel venue (Swarbrooke\& Horner 2001). MICE is a dynamic industries and its need innovation in several area to be developed like venues and technology (Buhalis, 2006; Cioffi, no date).

\section{Research Methodology}

The core idea of this research is to investigate the several factors that can influence the MICE industry in Pulau Seribu. For this research, the authors will be using secondary research method to be applied in the literature review chapter. The method will use as a tool to plan the approach, and also to collect the data and information needed for this research. The quantitative method will be applied as the data analysis.

\section{Research Tool}

Theauthors will be using quantitative method as the primary research and questionnaire is classified as quantitative method. According to Siniscalco and Auriat (2005), questionnaire that is using large sample is classified as a quantitative research method. Also the others reasons to using questionnaire is quick and easy to collect a larger sample data, and the data will be easy to analyse.

First is demographic, respondents will be asked about personal information. The reasons are to better assess and analyse the data, as it allows word tabulation for a deeper understanding of the data gathered.

Second is behavioural, in this category the authors will be asking about the people or companies behavior and also to know more about the market and awareness. The reason is to know about the market information and awareness about our survey study cases. Also the authors will be adding attitudinal type of question. In this category, the authors will ask about the attitudes and opinion of the people. The purpose is to know about the motivation of people actions and the future prediction of market and customers.

\section{Sampling}

To access the data the authors will be using Convenience Sampling method in this research. Convenience sampling is non probability sampling method, this method doing survey with a specific category of sample (Sincero, 2012). In this research the authors will be combining convenience sampling method with the quantitative research method. According to Etikan (2016), by combining quantitative and convenience sampling method the data will be more general and easy to analyze. The sample target of this survey is people who are 
working or own a business located near Pulau Seribu, and has a potential to using MICE facility in Pulau Seribu in the future.

\section{Result}

Kepulauan Seribu is an island with potential for tourism that offers great natural attractions. In the island there is an opportunity to develop MICE business tourism, by combining business tourism with cruise and yacht based activities to create a business tourism package (The Report, 2012). There is an increasing numbers of visitors in Pulau Seribu from just 468,296 total visitor in 2011, it has increased into 2,120,058 total visitors in 2014 (Munawaroh, 2016)

Pulau Seribu has also become a part of ten tourism destination priority plans, which were created by the ministry of tourism (Nurdiansyah, 2016, cited in Tempo, 2016). According to Esthy (2017, cited in Pikiran Rakyat, 2017), Pulau Seribu and Jakarta can combine to become a great MICE tourism destination. To realize this plan, the Indonesian government are also making a several improvements in Pulau Seribu.

The accumulation result of the questionnaires of this final project shows that the total respondent of this final project questionnaire is 40. Also from the questionnaires result shows that there are only 38 of responses that valid to be used to interpret the data result, the other two of the respondent choose a no to participate in the informed consent section. The overview of this interpretation questionnaire result data will be divided into three main sections results: demographic, behavioural, and attitudinal. Each of the questionnaire section practically is will be using to examine the literature review in chapter B.

Table 1. Respondents' business or company location

\begin{tabular}{ccc}
\hline Location & Frequency & Percentage \\
\hline Jakarta & 26 & $68,42 \%$ \\
Tangerang & 5 & $13,16 \%$ \\
Bekasi & 3 & $7,89 \%$ \\
Others & 4 & $10,53 \%$ \\
Total & $\mathbf{3 8}$ & $\mathbf{1 0 0 \%}$ \\
\hline
\end{tabular}

The table 1 shows that the majority of the respondent business or company location is based on Jakarta with the total of frequency around 26 $(68,42 \%)$ responses out of 38 total respondents. When the other located in 
Tangerang around $5(13,16 \%)$, Bekasi $3(7,89 \%)$, and other location for 4 $(10,53 \%) . \%)$. It can be concluded that the result data of this questionnaire will be more related on the business or company that located in Jakarta.

Table 2. Respondents' business or company duration

\begin{tabular}{ccc}
\hline Variable & Frequency & Percentage \\
\hline$<10$ years & 14 & $36,84 \%$ \\
$10-14$ years & 14 & $36,48 \%$ \\
$15-19$ years & 3 & $7,89 \%$ \\
$>20$ years & 7 & $18,42 \%$ \\
Total & $\mathbf{3 8}$ & $\mathbf{1 0 0 \%}$ \\
\hline
\end{tabular}

Table two shows that majority of the respondent business or company is classified as a new business. It can be seen from the total frequency of how long that the business has been established, most of the respondents answer with $<10$ and 10-14 year with the total $14(36,84 \%)$ responses. This indicated that the outcome of this research not might be cover all the business or company that has been established for a long period of time.

Table 3. Respondents' Businesses or Company Type

\begin{tabular}{ccc}
\hline Type & Frequency & Percentage \\
\hline Services & 19 & $50 \%$ \\
Merchandising & 6 & $15,79 \%$ \\
Manufacturing & 2 & $5,26 \%$ \\
Others & 11 & $28,95 \%$ \\
Total & $\mathbf{3 8}$ & $\mathbf{1 0 0 \%}$ \\
\hline
\end{tabular}

As reflected in table three, $50 \%$ business or company type of the respondents in this research questionnaire is based on service provider with total 19 frequencies responses. This result indicated that outcome of the questionnaire result will be more related to service provider business or company basis, and may not be generalized to every type of business or company. 
Factors Influencing MICE Tourism In Pulau Seribu, Jakarta, Indonesia

Table 4. Respondents’ Business or Company Size

\begin{tabular}{ccc}
\hline The Number of Employee & Frequency & Percentage \\
\hline $5-9$ & 14 & $36,84 \%$ \\
$10-19$ & 9 & $23,68 \%$ \\
$20-29$ & 1 & $2,63 \%$ \\
$\geq 30$ & 14 & $36,84 \%$ \\
Total & $\mathbf{3 8}$ & $\mathbf{1 0 0 \%}$
\end{tabular}

Table four shows that the majority of the respondents' business or company with 5-9 and 30< with total $14(36,84 \%)$ frequencies responses. It can be concluded that the average respondents that participate in this research questionnaire are equal, whether they come from a small or a big business or company.

\section{Summary of Demographic}

The outcome of this demographic section is basically an overview of the personal information of the respondents. The majority of respondents' company or business are based on Jakarta $26(68,42 \%)$, which is correlated with the target sample of the research. The average of business or company being established around less than 10 up to 14 year is $14(36,84 \%)$. As well as the $50 \%$ of the respondents' business or company type is service provider, with the average size of the business or company around 5-9and $\geq 30$ with total $14(36,84 \%)$.

\section{Behavioural}

Type of MICE Activity in 2017

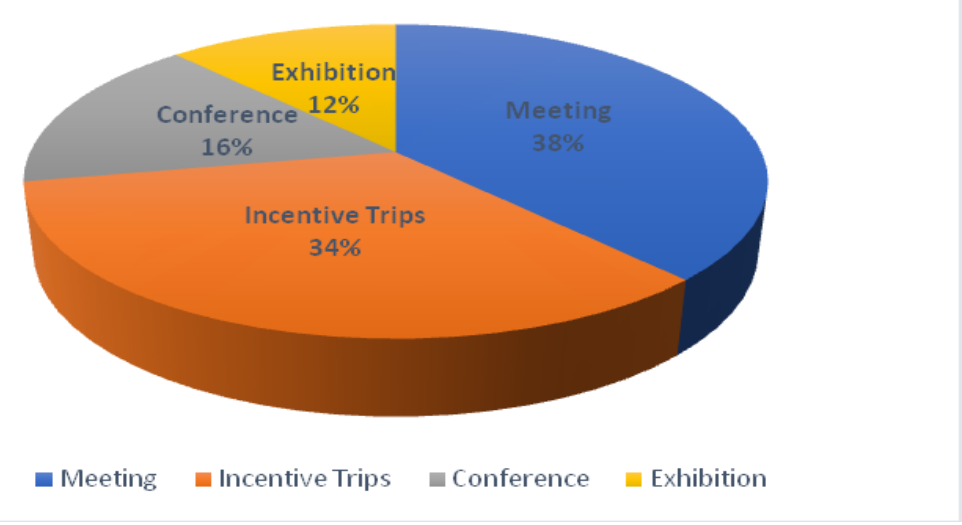

Figures 1 Type of MICE held by respondents 
From the figures 1 present the result data of MICE type being in 2017 by respondents business or company. The result of this questionnaire is dominated by meeting with 23 (38\%) out 38 respondents, followed by the incentive tripswith the total frequency of $21(34 \%)$ responses.

Table 5 Frequency of using own MICE facility in 2017

\begin{tabular}{ccc}
\hline Type & Frequency & Percentage \\
\hline $1-2$ times & 16 & $42,1 \%$ \\
$3-5$ times & 15 & $39,5 \%$ \\
$5-10$ times & 2 & $5,3 \%$ \\
More than 10 times & 5 & $13,2 \%$ \\
Total & $\mathbf{3 8}$ & $\mathbf{1 0 0} \%$ \\
\hline
\end{tabular}

Table 5 shows frequency of the respondents using their internal MICE facility in yearly basis. The result is the average of the respondents using their own internal facility not quite often with around 1-5 times in a year, it can be seen from the total majority frequencies of variable 1-2 times with $16(42,1 \%)$ and variable 3-5 times with 15 (39,5\%).

Table 6 Frequency of using external MICE facility in a year

\begin{tabular}{ccc}
\hline Type & Frequency & Percentage \\
\hline $1-2$ times & 17 & $44,7 \%$ \\
$3-5$ times & 15 & $39,5 \%$ \\
$5-10$ times & 3 & $7,9 \%$ \\
More than 10 times & 3 & $7,9 \%$ \\
Total & $\mathbf{3 8}$ & $\mathbf{1 0 0 \%}$ \\
\hline
\end{tabular}

This result of question is contradicted with the result of the previous question about frequencies of internal MICE usage, which is state in the previous result that the highest average variable responses are 1-5 times in a yearly basis. When the result of this question is also in the same highest average variable, which might be indicated that the respondent business or company infrequently held a MICE activity.

\section{Summary of Behavioural}

In this behavioural questionnaire section the respondents are asked to fill up five questions to examine their behaviour and awareness toward the research topic. The result is identifying that meeting is the most frequently held MICE activity. Also there is a contradicted question result between frequencies of internal and external facility usages in this section, which is indicated that the respondent, business or company infrequently held a MICE activity. 


\section{Attitudinal}

Respondents Awareness toward Pulau Seribu as MICE Destination

Table 7 presents the respondents awareness toward Pulau Seribu as MICE destination. The results indicated that the majority of the respondents are aware of Pulau Seribu as MICE destination; it was proven by the total frequencies with $29(76,3 \%)$ responses said yes.

Table 7 Respondents Awareness toward Pulau Seribu as MICE Destination

\begin{tabular}{ccc}
\hline Type & Frequency & Percentage \\
\hline Yes & 29 & $76,3 \%$ \\
No & 9 & $23,7 \%$ \\
Total & $\mathbf{3 8}$ & $\mathbf{1 0 0 \%}$ \\
\hline
\end{tabular}

Table 8 Respondents Experiences of Booking MICE Facility in Pulau Seribu

\begin{tabular}{ccc}
\hline Type & Frequency & Percentage \\
\hline Yes & 12 & $31,6 \%$ \\
No & 26 & $68,4 \%$ \\
Total & $\mathbf{3 8}$ & $\mathbf{1 0 0 \%}$ \\
\hline
\end{tabular}

The findings show that the majority of the respondents are never booked MICE facility in Pulau Seribu. It is proven with 26 (68,4\%) respondents answer no when being asked if they have ever booked MICE facility in Pulau Seribu.

Table 9 indicated that majority of the respondents choose infrastructure as the main factors that need to be developed in Pulau Seribu. Furthermore, in the tables shows the evidence that the respondents choose infrastructure to be developed in Pulau Seribu with $27(71,15 \%)$ responses. With this finding it has consolidated the hypothesis from other several previous questions, that infrastructure is the main factor that lacking in Pulau Seribu and need to be developed.

Table 9 Factors to be developed in Pulau Seribu as MICE Destination

\begin{tabular}{ccc}
\hline Type & Frequency & Percentage \\
\hline Infrastructure & 27 & 71,15 \\
Marketing & 11 & $28,9 \%$ \\
Labor Force & 0 & 0 \\
Others & 0 & 0 \\
Total & $\mathbf{3 8}$ & $\mathbf{1 0 0 \%}$ \\
\hline
\end{tabular}

The overall main factors that need development is infrastructure in order to improve Pulau Seribu quality as MICE destination. 


\section{E. Discussion}

The majority of the respondents are from service provider business or based on Jakarta. The respondents range from small to big size business and company which have been established around 10-15 years. There is some contradiction result about internal and external MICE facility usage question. The level awareness of the respondent about Pulau Seribu as MICE destination is high, but low levels of experience the location itself. Moreover, with the result of more than 50\% respondents aware of Pulau Seribu as MICE destination, it can be indicated that Pulau Seribu already possessed one of the important factor to develop MICE industry based on Narowack theory.

However, infrastructure is the main factor that lacking in Pulau Seribu and need to be developed in order to improve the island competitiveness as MICE destination. The government should be confident with their effort in developing MICE Industry especifically at Pulau Seribu. The company and business relevant to MICE industry are supporting the government in developing Pulau Seribu.

\section{F. Conclusion}

Pulau Seribu has a great potential to evolve its form of business from just a leisure to a business leisure category. Theresearch indicates that companies especially in service providers are aware of the opportunities to have MICE at this island. Despite the island'sgood prospect to be a MICE destination, Pulau Seribu needs to improve and start a sustainable development in order to grow the industry to the maximum potential of success. Behaviour of man changes through time, thus, the development plan will be a great success by providing what people demand and what people need. The private companies should be able to cooperate with the government in this development process. Lastly, the sustainability of Pulau Seribu should be monitoredand taken care in an appropriate structured plan.

\section{REFERENCE}

Aldrich, J. (1996) „The Course of Marshalle's Theorizing about Demand."History of Political Economy, 28:2, pp. 172-213. [Online][Accessed 11th November 2017]

ASEAN. (2016) ${ }^{e e}$ ASEAN MICE Venue Standards ${ }^{e e}$.ASEAN. [online][Accessed on21st November 2017]

Arnold, R. A. (2007) Economics. 8th ed., United States of America: Cengage Learning. 
Avramović, M.; Perić, G.; Komadina, M. (2016) „Trends In Business Tourism With a Special: Focus On The City of NI As s Conference Destination. "Journal of Economics, Management and Informatics, 7:1, pp. 4759.

Bastola, R. K. (2012) The Impact of The Development of The Tourism IndustryOn The Lifestyle of The Host Community. Centria University of AppliedSciences.

Berita Jakarta. (2015) KepulauanSeribuDidorongJadi Sister Island.(Thousand IslandDriven to be Sister Island). Berita Jakarta. [online][Accessed on $26^{\text {th }}$ September 2017]

Brotherton, B.; Wood, R.C. (2008)'The SAGE Handbook of HospitalityManagement'. London: SAGE Publication Ltd.

Buhalis, d.; Costa, C.; Ford, F. (2006) Tourism Business Frontiers. 1st ed., Great Britain: Butterworth-Heinemann.

Burkhard, S. N. (2016) 7 Travel Trends for 2017 That Will Drive The GlobalTourism Industry. 5th December. Trekk Soft. [Online][Accessed on 13 th November 2017]

Butler, R. W. (2006) The Tourism Area Life Cycle, Volume 1. 1st ed., Great Britain: Cromwell Press.Center for the Study of Social Policy. (2007) Customer Satisfaction:Improving Quality and Access to Services and Supports in Vulnerable Neighborhoods, What The Research Tells Us. Unknown place of Publication:Center for the Study of Social Policy. [Online][Accessed on 3rd November 2017]

Central statistic agency of DKI Jakarta . (2017). Kunjungan Wisatawan Mancanegara Ke Provinsi DKI Jakarta. (International Tourist Visits to DKI Jakarta). Indonesia: Central statistic agency of DKI Jakarta. [Online][Accessedon 3rd December 2017]

Center for the Study of Social Policy. [Online][Accessed on 3rd November 2017] https://www.cssp.org/publications/constituents-co-invested-inchange/customer-satisfaction/customer-satisfaction-what-research-tellsus.pdf

Cioffi, L. (no date) How Innovation is Transforming MICE Travel.Pata Conversation. [Online][Accessed on 20th November 2017]. http://www.pataconversations.com/lori-cioffi-northstar-mice-travel/

Etikan, I., Musa, S. A., \& Alkassim, R. S. (2016). Comparison of Convenience Sampling and Purposive Sampling. American Journal of Theoretical and Applied Statistics, 5, 1-4.

Hayward, P. (2000) Leisure and Tourism. 1st ed., Great Britain: Heinemann. Hing, N.; McCabe, V.; Lewis, P.; Leiper, N. (1998) "e Hospitality trends in the Asia Pacific: a discussion of five key sectors ${ }^{\text {ee }}$. Emerald Insight. [online][Accessed $\quad$ on $\quad 24^{\text {th }} \quad$ September 2017 ] http://www.emeraldinsight.com/doi/full/10.1108/09596119810240852 
Holloway, J. C.; Humphreys, C. (2012) The Business of Tourism. 9th ed., Great Britain: Pearson Education Limited.

Hotelrez. (2015) Bleisure: a growing trend in Business Travel. 16th March. Hotelrez. [Online][Accessed on 15th November 2017]

HR in Asia. (2016) MICE Destinations in Asia: For Corporate Events \& Activities. 7th ICCA. (2016) "ICCA Statistic Report Country \& City Rankingee.Iccaworld. [online][Accessed on 15th November 2017]IRSA.(2016) Tourism and Sustainable Regional Development in Indonesia.

UNPAD PRESS. Indonesia Government. (2009) Undang-Undang Republik Indonesianomor 10.Tabun 2009: Tentang Kepariwisataan. (Law Of Therepublicof Indonesianumber10. Year 2009: About Tourism). Indonesia: Indonesia Government. [Online][Accessed on $1^{\text {st }}$ December 2017]

Indonesia Ministry of Tourism. (2015) RencanaStrategi: PengembanganDestinasi Dan IndustriPariwisataTahun 2015-2019. (Strategic Plan:Destination Development and Tourism Industry Year 2015-2019). Kemenpar.go. [online][Accessed on $25^{\text {th }}$ September 2017]

Indonesia Tourism. (2017) A Majestic Tourist Destination: Thousand IslandsNational Park Indonesia. 8th August. Indonesia Tourism. [Online][Accessedon 3rd December 2017]

Klimek, k. (2013)'Destination Management and Sustainable TourismDevelopment'. Saarbrücken: LAP LAMBERT Academic Publishing.

Ladkin, A.; Spiller, J. (2000) Meetings, Incentives, Conferences and ExbibitionIndustry. 1 st ed. [Google Books] Travel \& Tourism Intelligence.

Lichy, J.; McLeay, F. (2017) „Bleisure: motivations and typologies. “ournal of Travel \& Tourism Marketing, pp. 1-4. [Online][Accessed on 14th November2017] http://www.tandfonline.com/doi/ref/10.1080/10548408.2017.1364206 scroll $=\mathrm{t}$

Lickorish, Leonard J. and Carson L. Jenkins (1997). An Introduction to Tourism [online][Accessed on 22 ${ }^{\text {nd }}$ September 2017]

Lonely Planet. (no date) Jakarta Is a Journey of Flavours: Welcome toJakarta. Lonely Planet. [Online][Accessed on 2nd December 2017]

Maslow, A. H. (2012) A Theory of Human Motivation. 1st ed. [Google Books] United States of America: Start Publishing LLC.

Mason, P. (2008) Tourism Impact, Planning, and Management. 2nd ed., New York: Routledge.

Middleton, V. T. C.; Clarke, J. R. (2001) Marketing in Travel and Tourism. $3^{\text {rded. }}$ Great Britain: butterworth and Heinemann.

Patil, S. (2013) Five Main Factors Influencing the Growth of Tourism WithDiagram: Factors influencing the growth of tourism. 20th July. ArticleJunction. [Online][Accessed on 10th November 2017] http://articles- 
junction.blogspot.ch/2013/07/five-main-factors-influencing-growthof.html

PikiranRakyaat. (2017) Asistensi MICE KepulauanSeribudan Kota TuaJakarta. (Assistance of MICE KepulauanSeribu and Old Town in Jakarta). 6thMay. Indonesia: PikiranRakyaat. [Online][Accessed on 3rd December 2017] http://www.pikiran-rakyat.com/wisata/2017/05/06/asistensimice-kepulauan-seribu-dan-kota-tua-jakarta-400597

Pons, P. O. (2016) Cultures of Mass Tourism: Doing the Mediterranean in the Age of Banal Mobilities. 1st ed., Routledge.

Sezgin, E.; Yolal, M. (2012) „Golden Age of Mass Tourism: Its History and Development." Visions for Global Tourism Industry - Creating and SustainingCompetitive Strategies. „First online ee published 18th April 2012. [Accessed on1st November 2017] http://cdn.intechopen.com/pdfs/35520.pdf

Sharma, Shavita and Sidharth Srivastava. 2018. Relationship Between Service Quality and Customer Satisfaction in Hotel Industry. Tourism Research Journal. 2 (1), $42-49$.

Siniscalco, M. T.; Auriat, N. (2005) „Questionnaire Design.“QuantitativeResearch Methods in Educational Planning. France: UNESCO.[Online][Accessed on 9th December 2017] http://unesdoc.unesco.org/images/0021/002145/214555E.pdf

Sincero, S.M. 2012. "Survey Response Scales." https://explorable.com/survey -response-scales (accessed September 22, 2014).

Smagina, N. (2017) ${ }^{\text {ec }}$ The internationalization of the Meetings-, Incentives,Conventions- and Exhibitions- (MICE) industry:Its influences on the actors inthe tourism business activity ${ }^{\text {ee }}$ Y Yadda. [online][Accessed on $24^{\text {th }}$ September http://yadda.icm.edu.pl/yadda/element/bwmeta1.element.cejsh6b0dcc47-f167-47ab-9d91-daeddb4aa9d1/c/06.pdf

Statista. (2016) "e Global travel and tourism industry - Statistics \&Facts". Statista. [online][Accessed on 22 ${ }^{\text {nd }}$ September 2017]

Statista. (2017) Global business travel spending growth forecast from 2015 to2020. [Online][Accessed on 14th November 2017]

Sylla, M; Chruściński, j.; Drużyńska, P.; Płóciennik, P.; Osak, W. (2015) "Opportunities and Limitations For MICE Tourism Development In D .eTourism. 25:2, pp. 118-124.

Swarbrooke, J.; Horner, S. (2001) Business Travel and Tourism. 1st ed., Great Britain: Butterworth and Heinemann. Sylla, M; Chruściński, j.; Drużyńska, P.; Płóciennik, P.; Osak, W. (2015) „Opportunities and Limitations For MICE Tourism Development In D ."Tourism. 25:2, pp. 118-124. Talbot, D. (2015) The importance of qualitative research and the problem 
of mass data gathering. 14th July. Linkedin.[Online][Accessed on $13^{\text {th }}$ December 2017]

Tempo. (2015) 'ee Jakarta to Develop MICE Tourism Concept ${ }^{\text {ee }}$ Tempo. [online][Accessed on $27^{\text {th }}$ September 2017]

Tempo. (2016) ProspekBisnis MICE Indonesia Bagus, Tapi... (Business

Prospects MICE Indonesia Is Good, But ...)

Indonesia:Tempo. [Online][Accessed on $3^{\text {rd }}$ December 2017]

Tempo. (2016) Target 12 JutaTuris Asing, KementerianPariwisataAndalkan

10 TempatIni. (Targeting 12 Million Foreign Tourists, Ministry of Tourism Rely on 10 Places). Indonesia: Tempo. [Online][Accessed on 3rd December 2017]

The Team.(2015) Up \& Coming MICE Destinations in Asia. 11th August. Mice

Industry News. [Online][Accessed on 21th November 2017]

The Report. (2012) The Report: Indonesia, 2012. [Google Books] Oxford

Business Group.

UNWTO. (2016) World Tourism Organization Annual Report 2016. [Online][Accessed on 15th November 2017]

UNWTO. (2017) Making tourism a tool to fight poverty: ten years of the ST-EP Initiative. UNWTO. [Online][Accessed on 12th November 2017]

UNWTO. (2017) Why Tourism?; Tourism-an economic and socialphenomenon. UNWTO. [Online][Accessed on 13th November 2017]

Weaver, D. (2013) 'Sustainable Tourism'. New York: Routledge. 